\title{
Taxation of e-commerce in China: applying US experience
}

\author{
Chen Jing \\ International Business Faculty \\ Beijing Normal University \\ ZhuHai, China
}

\begin{abstract}
The study provides a detailed overview of the sales tax on e-commerce transactions in America since 1998. While after the issue of Market place Fairness Act in 2013, the American government would like to create fair market environment, which means collecting the same taxation same as the traditional retail industry. In China, electronic commerce enterprise is developing rapidly, E-commerce such as Taobao, poses a long-term threat to the tax systems as consumers prefer to purchase goods and services online while the current tax system has not cover the internet sales, which will reduce the states collection of tax. The study throws some suggestions on tax collections in China.
\end{abstract}

Keywords- electronic commerce; taxation; business enterprises; China

\section{INTRODUCTION}

Before 1997, the studies in United States on e-commerce taxation policies took different opinions. Later in 1998, President Clinton signed the Internet Tax Freedom Act in order to protect the development of e-commerce. The internet users are relived of the following items: (1) the imposition of state tax on internet access charges; (2) discriminatory state taxes; and(3)multiple state taxation of the same transaction or income. We can find that the internet users also had to pay the same tax as the traditional trade (such as telephone, mail order) of the same tax, but the local government can't collect the same tax in another state. The Internet Tax Freedom Act was only placing a ban on new internet tax. With the help of the Act, electronic commerce developed rapidly in America. Later in November 28, 2001, the United States issued Internet Tax Non - Discrimination Act, which makes the free tax environment extended until November 2003.

Then, on December 3, 2004, the Internet Tax Non Discrimination Act had been modified and the period of free tax environment has been extended to November 2007. With the support of the federal government's tax policy, research shows that about 150,000,000 Americans choose online shopping in 2012 and the data are still increasing at an annual rate of $10 \%$.

In recent years, however, the financial crisis in the word has taken the state of the local governments into a huge financial crisis. The government tried every means to increase fiscal revenue sources. As a result, the e-commerce industry will undoubtedly become the target of the government. Statistics of Department of commerce show that: the internet total transaction amount is $\$ 225.5$ billion in 2012. According to the sessions of the national state senator estimates, the loss of the internet sales tax is about $\$ 23$ billion, as Amazon is the largest e-commerce enterprises, the state governments have already tried to charge the Amazon sales tax, and the tax is called the "Amazon tax". Amazon companies using the United States Supreme Court in 1992, "Kewell company v North Dakota" case, which held that only one company in a state owned entity shop or "actual connection", it would be collected the tax. Amazon and other large network vendors use a large number of subsidiaries and branches which has agency business functions to evade taxes. On May 6, 2013, the United States passed a market fair act, if the final bill would be passed by the house of representative; it means that the electric business enterprise needs to pay sales tax. The tax will be collected by the consumer's government (the online shop earning below $\$ 1$ million will be free).

\section{THE INFLUENCE OF THE UNITED STATES TAX POLICIES TO E-COMMERCE}

Endicia, an electronic stamp company in the United States found that $44 \%$ of people said that if the market fair act had been passed as an act, they will reduce the online shopping. At the same time, the survey also found that the young people between 18 to 25 years old, who will not only reduce the online shopping, and go to the nearby shops, and the result is just what "the national retail federation" wanted. The national retail federation states that, the current tax law makes the traditional shop becomes the showrooms. Consumers always try to wear, try to use and even try to eat in the physical stores, but they will buy the same products in the Amazon, Ebay and other online shops in order to avoid sales tax, which is very unfair for physical stores. On the other side, there is still a significant part of the opponents worry that the proposal of the legislative council will affect the growth of electronic commerce, and the small micro enterprise will be impacted heavily. Network sellers such as Ebay states that if the government ask the small micro enterprises take the same tax as large network companies like Amazon ,it is quite unfair. As a result, the government should mitigate tax to the online sellers whose employees are fewer than 50 or the annual turnover less than 10 million. Above all, the United States government would like to create a good competition environment for the E-commerce 
business. When e-commerce was beginning to develop, the government prevented the E-commerce from internet sales tax and after it has developed to a certain size, which has enough power to compete with the traditional entity industry, the government took their efforts to build a fair, reasonable market environment. As a result, the e-commerce industry and traditional retail industry will compete fairly and they can give a more convenient, quick, efficient service for consumers.

\section{THE SUGGESTIONS ON THE INTERNET SALES TAX IN CHINA.}

A. The development of China's e-commerce enterprise scale gradually affects the development of traditional retailing, thus the government should establish a fair market competition environment, and at the same time the interests of small microelectronics business enterprise must be protected.

E-commerce industry in China has roughly experienced three periods, from 1999 to 2002, only a few of the netizens, and few electronic retailing. 8848 electronic company, which was registered at that period have collapsed. From 2003 to 2007,the E-commerce has began to develop, such as Alibaba, DangDang, has become the leader of E-commerce in China; Since 2008 e-commerce has enter into a explosive growth stage, on November 11, 2013 the total sales of Alipay has increased to more than 57,100,000,000yuan. As a result, the retailers suggest that E-commerce taxing is necessary for fairness to retailers. They claim that tax policy should not favor one form of enterprise over another.

\section{B. Planning for Internet Sales Tax in China}

Nowadays, E-commerce has become very popular in the clothing, textile and household appliances, even we can say that no business can operate without a website, and no transaction can be operated without internet. Statistics show that the most popular products in China are clothing, electronics, computers, household products, and food etc. They have to pay sales tax, value-added tax and consumption tax when they buy the products in the street store. Did all the E-commerce buyers need to pay all kinds of the tax in China? As Chinese government is trying to collect value added tax instead of sales tax, we would like to suggest the lawmakers directly collect value-added tax(or we can call it as internet sales tax) and give a detailed description about the taxation. In this way, the consumer will continuously choose online shopping as well, since they can see how much value has added in this product. On the other hand, the value-added tax is 17 percent in China, as opposed to sales tax which is 6.75 in United States. For the international traders, the different tax rate is quite difficult for the business to enter into Chinese market.

\section{Using "third-party payment platform" to help the collection of internet sales tax}

Under Our country Present Company legal regime, all of the electronic commerce enterprise must pay the same taxes with the traditional entity enterprise. While the data shows that the United States government loss $\$ 62.1$ billion electronic commerce tax in 2011, and the Chinese government loss 115.7 billion Yuan electronic commerce in 2011. As the reason of this phenomenon is the government can't supervise the taxation on the internet. A sale which is made by an internet seller not located in the state where the sale was made is subject to a use tax in the state and a sales tax. In United States, if a consumer in California purchases a product from a mail-order retailer based in Tennessee, the retailer must collect a use tax for California, if there is sufficient nexus to the state of California. While if an internet-based retailer in California has no offices, it will probably not have a sufficient nexus to be required to collect a use tax. While in China, most of the internet consumers prefer to pay a lower price instead of asking for the invoice, but almost all of the online sales require consumers to pay, so the third party payment platform, become the carrier to pay a tax. In short, E-commerce taxation should be economically neutral, which is there should be an equitable distribution of tax revenue.

E-commerce has different meanings between B2B, B2C, and $\mathrm{C} 2 \mathrm{C} . \mathrm{B} 2 \mathrm{~B}$ means. B2B means business to business. In view of the "big data " form of electronic commerce dynamic business and trade activities, it is better to establish the electronic commerce tax registration system and the network tax certification center certification system in order to collecting electronic merchants legal information. The internet taxpayers may be required to register in e-commerce enterprises tax system. The internet sellers must go to the network trading registration and then they can conduct the network. The tax registration number must appear on their business web site. In this way, the supervisor will get the trade information immediately. At the same time, the internet seller who has not registered in the center will be banned in the network transactions. On the other hand, the data of the E-commerce is easier to get, it is better to distinguish different kinds of product, and then make different kinds of tax according to these data.

\section{CONCLUSIONS}

With regard to the internet sales tax, it is better to match the current tax system. When the e-commerce tax policies were passed by the government, it should be combined with characteristics of China's e-commerce transactions. It can also set the tax on the basis of the current tax system or learn American model, which doesn't set new tax referred to Ecommerce. Research on the current e-commerce transactions tax system becomes the most important task for the government. What' more, they should take a clear concept of the e-commerce taxpayers, tax rates, tax taxation elements, and make sure that the tax policies are not prevent the development of the E-commerce . They should also consider 
the follows: (1) the VAT (Value Added Tax), it is better to consider tangible goods in accordance with the interim regulations on value-added Tax rules, which impose a $17 \%$ value-added tax as the United States and the European Union VAT system. If the individual consumers buy physical goods or goods via the Internet and take the traditional transport mode, and it is suitable to collect VAT Tax; with regard to other forms of remote transaction such as telephone or postal system, the VAT system is also available. With regard to merchandise from a third country, as we have to consider tariffs it can be the treated as second-hand goods trading, pawn, pledge, trading behavior. Value added tax is imposed on e-commerce sales commodity using simple procedure. (2)With regard to the sales tax, it is that the online sales of electronic products assets $5 \%$ sales tax, which could encourage the business development. As a result, it is better to encourage e-commerce enterprises enjoy the same preferential taxation policy as information software enterprises, high-tech enterprises, technology service enterprises. As well, with regard to the logistics, payment and settlement, design, finance and other emerging ecommerce services ,it is better to take preferential taxation, which will reduce overall e-commerce business tax rate.

\section{References:}

[1] Malaga, Ross A . Responding To State Sales Tax Laws For Online Retailers- A Case Study Of Amazon The States Journal of Applied Business Research; Nov/Dec 2012;28;6

[2] Arnold, William E, IV . Tax Enforcement In Virtual Worlds-Virtually Impossible? Syracuse Journal of International Law and Commerce; Fall 2012;40,1;

[3] $113^{\text {th }}$ CONGRESS S.743 IN THE HOUSE OF REPRESENTATIVES MAY 20,2013

[4] Robicheaux R. A. Estimates of Alabama Losses Due to ECommerce [R]. UAB School of Business, 2012.

[5] www.100EC.cn Chinese E-commerce Research Centre 